\title{
Correction to: Articles in Themed Issue: Health Financing in Sub-Saharan Africa
}

Published online: 30 November 2020

(c) The Author(s) 2020

\section{Correction to: Applied Health Economics and Health Policy https://doi.org/10.1007/s40258-019-00499-y https://doi.org/10.1007/s40258-019-00506-2 https://doi.org/10.1007/s40258-019-00508-0 https://doi.org/10.1007/s40258-019-00550-y https://doi.org/10.1007/s40258-020-00567-8 https://doi.org/10.1007/s40258-020-00597-2}

The following articles were originally published electronically on the publisher's internet portal without open access.

"Health Insurance in Sub-Saharan Africa: A Scoping Review of the Methods Used to Evaluate its Impact" https://doi.org/10.1007/s40258-019-00499-y

Copyright changed on [29.10.2020]

"Analyzing the Financial Sustainability of User Fee Removal Policies: A Rapid First Assessment Methodology with a Practical Application for Burkina Faso"

https://doi.org/10.1007/s40258-019-00506-2

Copyright changed on [6 November 2020]

"An Assessment of Domestic Financing for Reproductive, Maternal, Neonatal and Child Health in Sub-Saharan Africa: Potential Gains and Fiscal Space"

https://doi.org/10.1007/s40258-019-00508-0

Copyright changed on [29.10.2020]

The original articles can be found online at https://doi. org/10.1007/s40258-019-00499-y, https://doi.org/10.1007/s4025 8-019-00506-2, https://doi.org/10.1007/s40258-019-00508 -0, https://doi.org/10.1007/s40258-019-00550-y, https://doi. org/10.1007/s40258-020-00567-8, https://doi.org/10.1007/s4025 8-020-00597-2.
"Payment Arrangements for Private Healthcare Purchasing Under Publicly Funded Systems in Low- and Middle-Income Countries: Issues and Implications" https://doi.org/10.1007/s40258-019-00550-y

Copyright changed on [6 November 2020]

"Performance-Based Financing, Basic Packages of Health Services and User-Fee Exemption Mechanisms: An Analysis of Health-Financing Policy Integration in Three Fragile and Confict-Affected Settings" https://doi.org/10.1007/s40258-020-00567-8

Copyright changed on [9 November 2020]

"Evaluating Equity in Health Financing Using Benefit Incidence Analysis: A Framework for Accounting for Quality of Care" https://doi.org/10.1007/s40258-020-00597-2

Copyright changed on [13.10.2020]

With the authors' decision to opt for Open Choice the copyright of the articles changed on the listed dates to (C) The Author(s) 2020 and the articles are forthwith distributed under a Creative Commons Attribution-Noncommercial 4.0 International License, which permits any non-commercial use, sharing, adaptation, distribution and reproduction in any medium or format, as long as you give appropriate credit to the original author(s) and the source, provide a link to the Creative Commons license, and indicate if changes were made. The images or other third party material in these articles are included in the articles' Creative Commons licenses, unless indicated otherwise in a credit line to the material. If material is not included in the articles' Creative Commons licenses and your intended use is not permitted by statutory regulation or exceeds the permitted use, you will need to obtain permission directly from the copyright holder. To 
view a copy of this license, visit http://creativecommons.org/ licenses/by-nc/4.0/

The original articles have been corrected.

Funding Open Choice was funded by the African Economic Research Consortium.

Open Access This article is licensed under a Creative Commons Attribution-NonCommercial 4.0 International License, which permits any non-commercial use, sharing, adaptation, distribution and reproduction in any medium or format, as long as you give appropriate credit to the original author(s) and the source, provide a link to the Creative Commons licence, and indicate if changes were made. The images or other third party material in this article are included in the article's Creative Commons licence, unless indicated otherwise in a credit line to the material. If material is not included in the article's Creative Commons licence and your intended use is not permitted by statutory regulation or exceeds the permitted use, you will need to obtain permission directly from the copyright holder. To view a copy of this licence, visit http://creativecommons.org/licenses/by-nc/4.0/. 